Bangladesh J. Bot. 48(4): 981-987, 2019 (December)

\title{
COMPARATIVE ANATOMICAL STUDIES OF FOUR HYACINTHELLA SCHUR SPECIES GROWING IN TURKEY
}

\author{
SÜLEYMan DoĞU* \\ Department of Animal and Plant Production, Meram Vocational School, \\ Necmettin Erbakan University, Konya, Turkey \\ Keywords: Hyacinthella, Comparative anatomical studies
}

\begin{abstract}
In the present study, along with scape, leaf surface and mesophyll anatomy of four Hyacinthella species, H. nervosa (Bertol.) Chouard, H. hispida (J.Gay) Chouard, H. siirtensis B. Mathew and H. venusta K. Pers. were studied and the features were compared among the species in this research. After the analysis of data, it was seen that the scape anatomy is close to studied species. However, there are differences when the other species examined as seen in the epiderma has papillose protuberances only in H. nervosa. When the leaf mesophyll is observed, it is seen that $H$. siirtensis and $H$. venusta are equifacial, $H$. hispida is unifacial, $H$. nervosa is dorsiventral. Raphide crystals are seen in some of the mesophyll cells. While leaves are amphistomatic with anomocytic stomata in all taxa, indumentum and epidermal cell bigness of the surfaces show difference among the species.
\end{abstract}

\section{Introduction}

Asparagaceae is well defined based on the fruit and stamen characteristics. It differs from the related families Liliaceae and Colchicaceae by its baccate fruit and introsed stamens (Baker 1875). The family is represented by nearly 3600 species included in 143 genera in the world. The species of the family used as vegetable, ornamental and medicinal plants are distributed naturally at temperate, tropical and sub-tropical regions (The Plant List 2010). These members of the family are reported in the Flora of Turkey as 19 genera and 182 species (Ekim 2012).

Recently, the genus Hyacinthella Schur has been transferred from the family Hyacinthaceae to Asparagaceae. Hyacinthella species, which contain 13 species, are mostly distributed in Southeastern Asia, among them 3 species are distributed in South-eastern Europe (Persson and Wendelbo 1981, 1982, Persson and Persson 1992, 2001). It is represented by 12 species, 10 of them are endemic for Turkey (Ekim 2012).

Anatomical studies have been carried out successfully to clarify taxonomic position and help in the identification of different plant species (Dinç et al. 2011, Doğu et al. 2012). As well as macro- and micromophological characters, anatomical ones have been used for the resolution of taxonomic problems of monocots (Gilani et al. 2002). Taxonomic boundaries among some Hyacinthella species growing in Turkey are obscure due to the morphological similarity of the species. Because of this, there are some anatomical studies on some Hyacinthella species growing in Turkey (Yetişen et al. 2012, Tekin and Meriç 2013). The purpose of this study is to determine anatomical features of $H$. hispida, $H$. venusta, $H$. nervosa and $H$. siirtensis and to compare the species anatomically.

\section{Material and Methods}

Samples were collected from different localities in Turkey. A list of all taxa studied is provided (Table 1). Some plant samples collected from natural habitats in the flowering period were prepared as herbarium materials. Voucher specimens were deposited in the Herbarium of Necmettin Erbakan University. The others were fixed in $70 \%$ ethyl alcohol for anatomical

*Author for correspondence: <suleymandogu@gmail.com>. 
observations. The studies were performed in botanical laboratory of Necmettin Erbakan University using 15 samples for each species. Anatomical examinations, cross-sections of the leaves and scape were made together with the upper and lower surfaces of the leaves. An average of 25 preparations were made for each type of section and stained with basic fuchsin for easy identification of the tissues. Well stained sections covered with glycerin gelatin were made into permanent slides as described by Vardar (1987). The stained preparations were examined with an Olympus BX-50 microscope and photographed with a Canon EOS 450D camera. Dissimilar features of the four species were emphasized during the presentation of the results.

Table 1. The studied materials of Hyacinthella species.

\begin{tabular}{|c|c|c|}
\hline Species & Locality & Collection data \\
\hline H. hispida & $\begin{array}{l}\text { C5 MERSİN: Tarsus, Karakütük Köyü civarı, taşlık yamaçlar, } 700 \text { m, } \\
\text { 15.03.2011 }\end{array}$ & S. Doğu 2478 \\
\hline$H$. venusta & $\begin{array}{l}\text { C4 KARAMAN: Sarıveliler, Gülündere köprüsü civarı, yamaçlar, } 1700 \\
\text { m, 09.04.2011 }\end{array}$ & S. Doğu 2490 \\
\hline H. nervosa & $\begin{array}{l}\text { C6 GAZİANTEP: Gaziantep-Kilis yolu } 10 . \mathrm{km} \text {, Nafak mevkii, taşlık } \\
\text { yamaçlar, } 750 \mathrm{~m}, 12.05 .2012\end{array}$ & $\begin{array}{l}\text { M.Dinç } 3463 \\
\text { \& S. Doğu }\end{array}$ \\
\hline H. siirtensis & $\begin{array}{l}\text { C5 OSMANIYE: Kadirli, Çevlik köyü civarı, Pinus birliği açıklıkları, } \\
450 \text { m, 16.03.2011 }\end{array}$ & S. Doğu 2484 \\
\hline
\end{tabular}

\section{Results and Discussion}

In all species investigated, cross section of the scape is more or less terete shape. The epidermis is single-layered, with square and rectangular shaped cells in cross section, covered by a thick cuticle. It has no trichomes. But, there is papillar protuberance on some epidermal cells only in $H$. nervosa. Cortex is present under the epidermis. It is 2-6-layered and consists of orbicular or hexagonal parenchymatic cells. Underneath the cortex, the sclerenchymatic tissue constitute a circular band along the transection of the scape. When the sclerenchymatic band has 6-8-layered cells with thin walls and wider than the cortex in $H$. hispida, $H$. venusta and $H$. nervosa, it is 3-4-layered cells with thick walls and not wider than the cortex in $H$. siirtensis. The vascular bundles are distributed under the sclerenchymatic tissue. They are on two rows, those on outer row are very smaller as compared to those on inner one. Outer vascular bundles are located partly or completely within sclerenchymatic tissue. Pith immediately begins under the sclerenchymatic band and consists of parenchymatic cells. Vascular bundles in the inner row are found in parenchymal cells (Table 2, Fig. 1).

Epidermis is a single layered on both surface of leaf. The upper and lower epidermis are covered with a thick cuticle. The outer walls of epidermal cells are convex and thickened. There are simple and long trichomes on the both surface in $H$. hispida, but the epidermises lack trichomes in the other species. The stomata are visible in some transections of the leaf. The leaf is amphistomatic in all studied species. It is unifacial in $H$. hispida, equifacial in $H$. venusta and $H$. siirtensis, dorsiventral in $H$. nervosa. In other words, only spongy parenchyma is composed of 13 - 15 layered uniform and nearly orbicular cells in H. hispida; 1-2- layered palisade parenchyma beneath upper and lower epidermis and 10 - 15 layered spongy parenchyma between the two palisades are present in the leaf mesophyll of $H$. venusta and $H$. siirtensis; 1-2- layered palisade parenchyma beneath lower epidermis and $14-17$ layered spongy parenchyma beneath upper epidermis is present in the mesophyll of $H$. nervosa. The spongy parenchyma consists of nearly orbicular cells, but palisade parenchyma more or less cylindirical cells. Some mesophyll cells contain raphide crystals. Vascular bundles which have fibre strands are arranged in a single row in 
the central part of mesophyll. The vascular bundle in the midrib region is not conspicuously larger than the others (Table 2, Fig. 2).

Table 2. The anatomical characters of the studied Hyacinthella species in Turkey.

\begin{tabular}{|c|c|c|c|c|}
\hline & H. hispida & H. venusta & H. nervosa & H. siirtensis \\
\hline $\begin{array}{l}\text { Scape } \\
\text { epiderma }\end{array}$ & $\begin{array}{c}\text { Without } \\
\text { protuberances }\end{array}$ & $\begin{array}{c}\text { Without } \\
\text { protuberances }\end{array}$ & $\begin{array}{l}\text { With papillose } \\
\text { protuberances }\end{array}$ & $\begin{array}{c}\text { Without } \\
\text { protuberances }\end{array}$ \\
\hline $\begin{array}{l}\text { Scape } \\
\text { cortex }\end{array}$ & $\begin{array}{l}\text { The sclerenchymatic } \\
\text { band is composed of 6- } \\
8 \text {-layered, thin walled } \\
\text { cells and wider than the } \\
\text { cortex }\end{array}$ & $\begin{array}{l}\text { The sclerenchymatic } \\
\text { band is composed of } \\
6-8 \text {-layered, thin } \\
\text { walled cells and wider } \\
\text { than the cortex }\end{array}$ & $\begin{array}{l}\text { The sclerenchymatic } \\
\text { band is composed of } \\
6-8 \text {-layered, thin } \\
\text { walled cells and wider } \\
\text { than the cortex }\end{array}$ & $\begin{array}{l}\text { The sclerenchymatic } \\
\text { band is 3-4-layered, } \\
\text { thick walled cells and } \\
\text { not wider than the } \\
\text { cortex }\end{array}$ \\
\hline $\begin{array}{l}\text { Leaf } \\
\text { mesophyll }\end{array}$ & Unifacial & Equifacial & Dorsiventral & Equifacial \\
\hline $\begin{array}{l}\text { Upper leaf } \\
\text { surface }\end{array}$ & $\begin{array}{l}\text { Epidermal cells } 85.96- \\
317.31(198.57 \pm \\
70.05) \text { in length, } 51.00- \\
80.83(67.65 \pm 9.15) \text { in } \\
\text { width }\end{array}$ & $\begin{array}{l}\text { Epidermal cells } \\
227.00-506.45 \\
(359.27 \pm 98,77) \text { in } \\
\text { length, } 30.55-57.09 \\
(45.08 \pm 6.97) \text { in } \\
\text { width }\end{array}$ & $\begin{array}{l}\text { Epidermal cells } \\
183.84-313.76 \\
(258.95 \pm 51.27) \text { in } \\
\text { length, } 51.59-81.82 \\
(63.48 \pm 10.42) \text { in } \\
\text { width }\end{array}$ & $\begin{array}{l}\text { Epidermal cells } 262.71- \\
479.79(380.03 \pm \\
79.27) \text { in length, } 22.2- \\
40.79(30.63 \pm 4.77) \text { in } \\
\text { width }\end{array}$ \\
\hline $\begin{array}{l}\text { Lower leaf } \\
\text { surface }\end{array}$ & $\begin{array}{l}\text { Epidermal cells } 62.04- \\
308.58(176.29 \pm \\
75.72) \text { in length, } 45.88- \\
62.97(54.83 \pm 4.66) \text { in } \\
\text { width }\end{array}$ & $\begin{array}{l}\text { Epidermal cells } \\
207.12-508.97 \\
(416.72 \pm 98.73) \text { in } \\
\text { length, 20.23-32.71 } \\
(27.26 \pm 4.1) \text { in width }\end{array}$ & $\begin{array}{l}\text { Epidermal cells } \\
158.00-476.13 \\
(313.73 \pm 85.61) \text { in } \\
\text { length, 38.96-68.09 } \\
(46.73 \pm 7.08) \text { in } \\
\text { width }\end{array}$ & $\begin{array}{l}\text { Epidermal cells } 156.82 \text { - } \\
549.81(329.46 \pm \\
\text { 134.57) in length, } \\
24.16-43.21(32.81 \pm \\
5.49) \text { in width }\end{array}$ \\
\hline
\end{tabular}

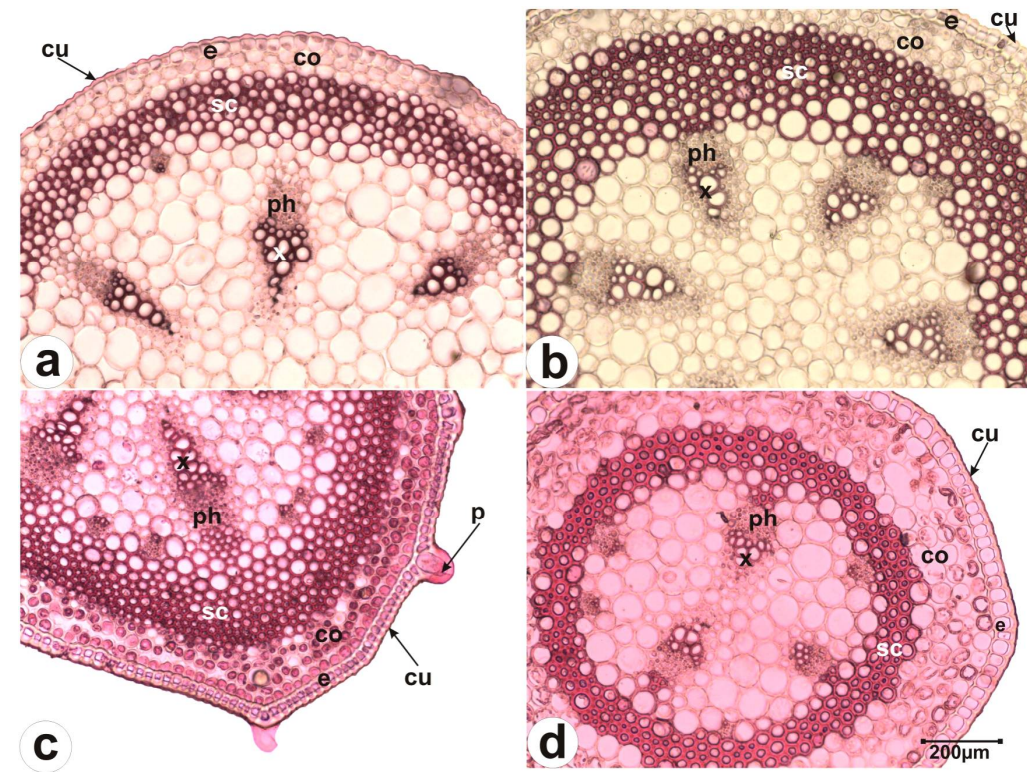

Fig. 1. The transverse section of the scape. (a): H. hispida, (b): H. venusta, (c): H. nervosa, (d); H. siirtensis. (cu): Cuticle, (e): Epidermis, (co): Cortex, (sc): Sclerenchyma, (ph): Phloem, (x): Xylem and (p): Papillar protuberance. 


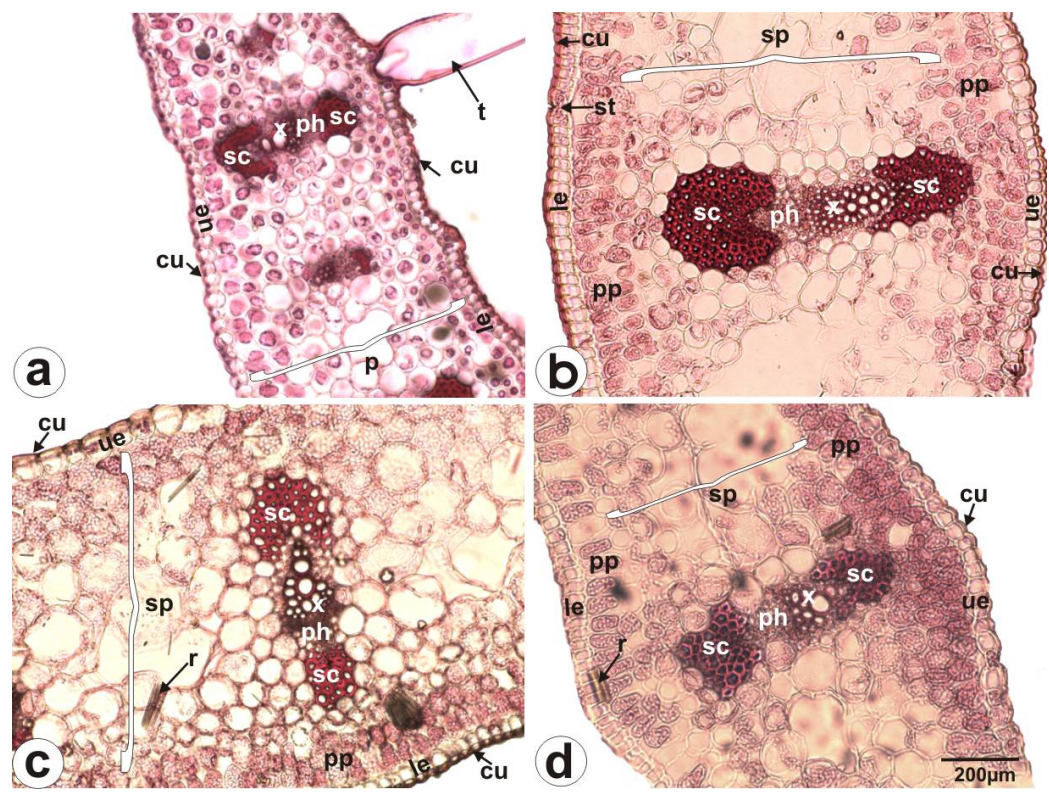

Fig. 2. The transverse section of the leaf. (a): H. hispida, (b): H. venusta, (c): H. nervosa, (d): H. siirtensis. (cu): Cuticle, (ue): Upper epidermis, (st): Stomata, (ph): Phloem, (x): Xylem, (pp): Palisade parenchyma, (sp): Spongy parenchyma, (le): Lower epidermis, (r): Raphide crystals, (m): Mesophyll and (t): Trichome.

The leaves are amphistomatic with anomocytic type stomata. The stomata are at the same level as the epidermal cells. Namely, they are mesomorphic type. In the leaf area, the number of the stomata per $\mathrm{mm}^{2}$, are on avarage 3 - 4 stomata in H. hispida and H. venusta, 5 - 6 stomata in $H$. nervosa and $H$. siirtensis on the upper surface. On the upper surface, epidermal cells are 85.96 $317.31 \mu \mathrm{m}(198.57 \pm 70.05)$ in length, $51.00-80.83 \mu \mathrm{m}(67.65 \pm 9.15)$ in width in $H$. hispida; epidermal cells are $227.00-506.45 \mu \mathrm{m}(359.27 \pm 98.77)$ in length, $30.55-57.09 \mu \mathrm{m}(45.08 \pm$ 6.97) in width in $H$. venusta; epidermal cells are 183.84-313.76 $\mu \mathrm{m}(258.95 \pm 51.27)$ in length, 51.59-81.82 $\mu \mathrm{m}(63.48 \pm 10.42)$ in width in $H$. nervosa; epidermal cells are 262.71-479.79 $\mu \mathrm{m}$ (380.03 \pm 79.27$)$ in length, 22.2-40.79 $\mu \mathrm{m}(30.63 \pm 4.77)$ in width in H. siirtensis (Table 2, Fig. 3).

In the leaf area, the number of the stomata per $\mathrm{mm}^{2}$, are on avarage $5-6$ stomata in $H$. hispida, 4 - 5 stomata in $H$. venusta, $H$. nervosa and $H$. siirtensis on the lower surface. On the lower surface, epidermal cells are $62.04-308.58 \mu \mathrm{m}$ (176.29 \pm 75.72$)$ in length, $45.88-62.97 \mu \mathrm{m}$ (54.83 \pm 4.66$)$ in width in H. hispida; epidermal cells are $207.12-508.97 \mu \mathrm{m}(416.72 \pm 98.73)$ in length, $20.23-32.71 \mu \mathrm{m}(27.26 \pm 4.1)$ in width in $H$. venusta; epidermal cells are $158.00-476.13$ $\mu \mathrm{m}(313.73 \pm 85.61)$ in length, $38.96-68.09 \mu \mathrm{m}(46.73 \pm 7.08)$ in width in $H$. nervosa; epidermal cells are $156.82-549.81 \mu \mathrm{m}(329.46 \pm 134.57)$ in length, $24.16-43.21 \mu \mathrm{m}(32.81 \pm 5.49)$ in width in $H$. siirtensis (Table 2, Fig. 4).

In the present study, the anatomical studies on Hyacinthella species in Turkey show that scape and leaf anatomy of the species are generally similar, but some anatomical features have diagnostic value due to interspecific variations (Atayeter 2007, Selvi et al. 2008, Yetişen et al. 2012, Tekin and Meriç 2013). 

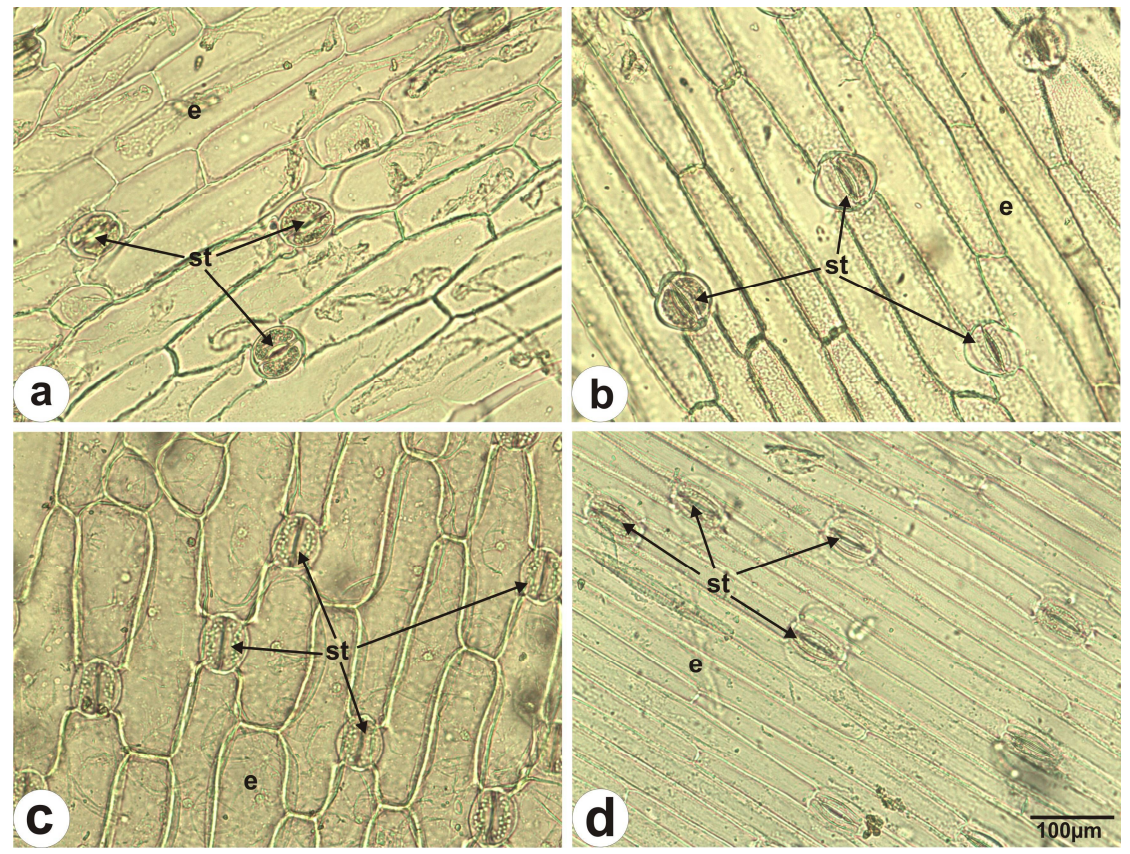

Fig. 3. Upper surface section of the leaf. a (a): H. hispida, (b): H. venusta, (c): H. nervosa, (d): H. siirtensis. (st): Stoma and (e): Epidermal cell.

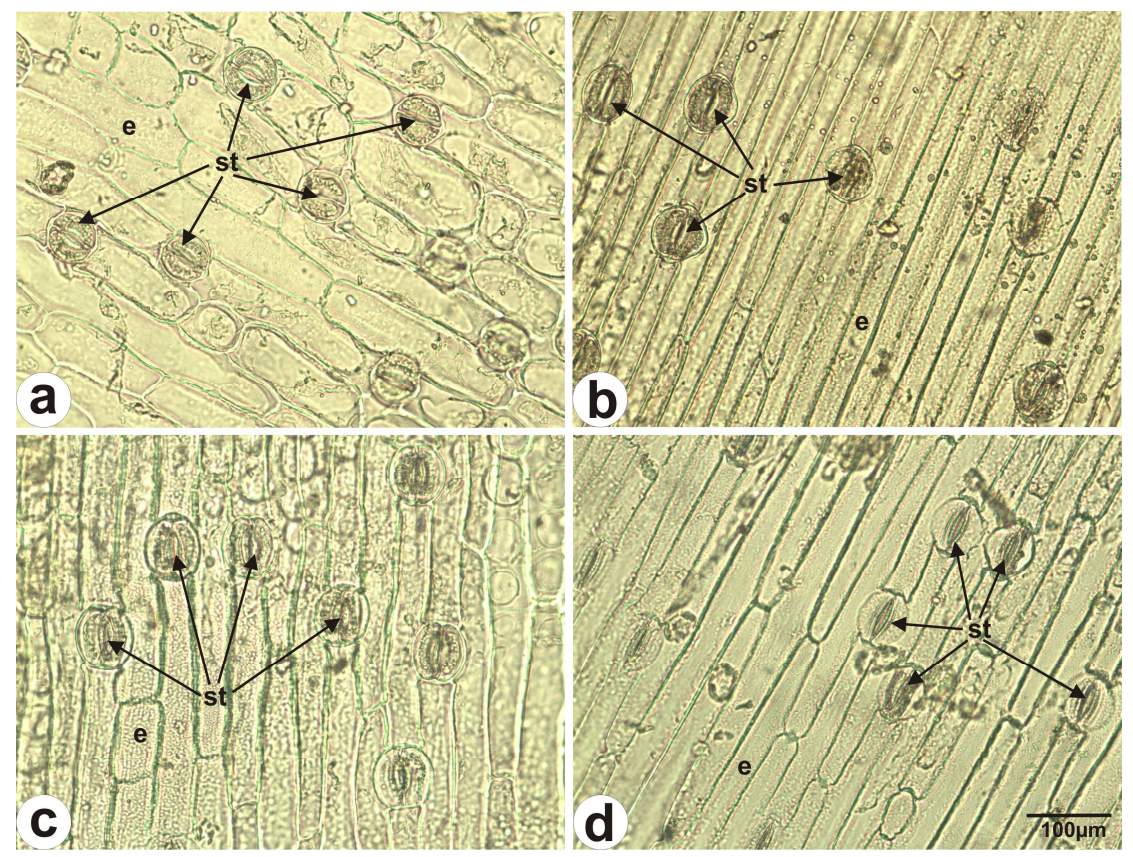

Fig. 4. Lower surface section of the leaf (a): H. hispida, (b): H. venusta, (c): H. nervosa, (d): H. siirtensis. (st): Stoma and (e): Epidermal cell. 
The anatomical features of the scape in the studied species are similar with those in $H$. acutiloba, $H$. campanulata, $H$. lazulina, $H$. glabrescens, $H$. lineata and $H$. heldreichii in terms of monolayer epidermis, 5 - 6 layered parenchymatic cortex, multilayer sclerenchyma tissues, various sized vascular bundles and parenchymatic pith. But, $H$. siirtensis differs from the other studied species by its less-layered sclerenchymatic band consist consisting of cells with thick wall. Epidermal protuberances are present only on the scape of H. nervosa. In adition, H. micrantha completely lacks sclerenchymatic tissue in its scape (Kandemir et al. 2000). Although there are raphide crystals in scape cortex of $H$. acutiloba (Tekin and Meriç 2013) and sand crystals in $H$. glabrescens (Yetişen et al. 2012), the other studied Hyacinthella species lack crystals in their scapes (Kandemir et al. 2000, Atayeter 2007, Selvi et al. 2008).

In the present and previous studies, mesophyll anatomy in the genus Hyacinthella shows difference among the species with regard to arrangement of the mesophyll. Leaf mesophyll is isolateral in the previously studied species (Kandemir et al. 2000, Atayeter 2007, Selvi et al. 2008, Tekin and Meriç 2013). Similary it is isolateral in $H$. siirtensis and $H$. venusta but unifacial in $H$. hispida and dorsiventral in $H$. nervosa.

The shape and distribution of calcium oxalate crystals in plant tissues can be taxonomically useful in monocotyledons (Prychid and Rudal 1999). The raphide crystals are present in mesophyll cells of H. acutiloba and H. campanulata (Atayeter 2007, Tekin and Meriç 2013). Similarly, there are raphide crystals in the studied species. But, $H$. lineata, $H$. micrantha, $H$. heldreichii and $H$. lazulina did not have raphide crystals in their leaf mesophyll cells (Kandemir $e t$ al. 2000, Atayeter 2007, Selvi et al. 2008).

\section{References}

Atayeter E 2007. The morphological and anatomical characteristics of some endemic Hyacinthella Schur (Liliaceae) taxa. M.Sc. Thesis, Selçuk University, Konya (in Turkish).

Baker JG 1875. Revision of the genera and species of Asparagaceae. J. Linn. Soc. Bot. 14: 508-632.

Dinç M, Doğu S and Bağcı Y 2011. Taxonomic reinstatement of Teucrium andrusi from T. paederotoides based on morphological and anatomical evidences. Nord. J. Bot. 29(2): 148-158.

Doğu S, Dinç M and Pınar NM 2012. Anatomical and micromorphological differentiation in the genus Moltkia Lehm in Turkey. Pak. J. Bot. 44(3): 1083-1090.

Ekim T 2012. Hyacinthella Schur. In: Güner A, Aslan S, Ekim T, Vural M and Babaç MT (ed.) Türkiye Bitkileri Listesi (Damarlı Bitkiler). Nezahat Gökyiğit Botanik Bahçesi ve Flora Araştırmaları Derneği Yayın1, İstanbul. pp. 97-98.

Gilani SS, Khan MA, Shinwari ZK and Yousaf Z 2002. Leaf epidermal anatomy of selected Digitaria species, Tribe Paniceae, family Poaceae of Pakistan. Pak. J. Bot. 34: 257-273.

Kandemir N, Akçin OE and Cansaran A 2000. A morphological and anatomical investigation on some geophytes distributed in the vicinity of Amasya. The Herb. J. Syst. Bot. 7(2): 127-147.

Persson K and Wendelbo P 1981. Taxonomy and cytology of the genus Hyacinthella (Liliaceae-Scilloideae) with special reference to the species in S.W. Asia. Part I. Candollea. 36(2): 158-175.

Persson K and Wendelbo P 1982. Taxonomy and cytology of the genus Hyacinthella (Liliaceae-Scilloideae) with special reference to the species in S.W. Asia. Part II. Candollea, 37(1): 513-541.

Persson K and Persson J 1992. A new species and additional chromosome counts of Hyacinthella in Turkey. Nord. J. Bot. 12(6): 615-620.

Persson K and Persson J 2001. Hyacinthella Schur (Hyacinthaceae) in the Balkan countries. Candollea, 55(2): 213-225.

Prychid CJ and Rudall PJ 1999. Calcium Oxalate Crystals in Motocotyledons: A Review of their Structure and Systematics. Ann. Bot. 84: 725-739.

Selvi S, Erdoğan E and Daşkın R 2008. Morphological, anatomical and ecological studies on Hyacinthella lineata (Liliaceae). Ekoloji. 68(17): 24-32.

Tekin M and Meriç Ç 2013. Morphological and anatomical investigations on endemic Hyacinthella acutiloba in Turkey. Biodicon. 6(1): 161-168. 
The Plant List 2010. http://www.theplantlist.org/browse/A/Asparagaceae.

Vardar Y 1987. Botanikte Preparasyon Tekniği. Ege Üniversitesi Fen Fakültesi Basımevi. pp. 25-26.

Yetişen K, Özdemir C, Küçüködük M and Akyol Y 2012. A morphological and anatomical study of Hyacinthella glabrescens (Liliaceae). Phytologia Balcanica. 18(3): 319-322.

(Manuscript received on 3 November, 2018; revised on 25 march, 2019) 